\title{
Talking Geography: on oral history and the practice of geography
}

\author{
Mark Riley \\ Department of Geography, University of Portsmouth, Portsmouth,PO13HE, UK. \\ David Harvey \\ Department of Geography, University of Exeter, Exeter, EX4 4RJ, UK.
}

\begin{abstract}
Introduction
Following the lead of the pioneering work of George Ewart Evans (1965) and others, oral history increased its influence as an academic approach in the 1970s and 1980s through the work of a small, but prolific, group of politically committed social historians (Perks \& Thompson, 1998). ${ }^{1}$ Perhaps surprisingly, however, there has been relatively little overt cross-pollination between oral history and geography in the intervening years. Indeed, Andrews et al (2006, p.158) have recently commented in Social and Cultural Geography that despite some emerging interest in the use of oral history within geography - discussed below, and of which this collection forms part - "in comparison to the scope of historical geography as a sub-discipline, $[\ldots]$ the use of oral history is a relatively rare undertaking". ${ }^{2}$ Based on an AHRC sponsored symposium held in 2004, this short collection of papers extends the published work within the discipline of geography that engages with oral history approaches and sketches an agenda for how the two may proceed in a mutually beneficial fashion. ${ }^{3}$
\end{abstract}

Reflecting the larger shift of the 'cultural turn' within geography, the practice of oral history itself has undergone considerable critical examination and revision in recent years. Indeed, as Smith and Jackson (1999, p.368) claim, oral history has moved from its previous position as representing "a rather heroic process of reclaiming "the voice of the past", to now being seen as a more complex and politicised endeavour, "whereby the historian plays an active role in the (re)constitution of the past, narrating histories and [...] literally 'writing culture"'. In their more detailed review, Perks and Thomson (2006) outline four paradigm shifts within theory and practice of oral history: the post-war renaissance of memory as a source of 'people's history'; the development, from the late 1970s, of 'postpositivist' approaches to memory and subjectivity; a transformation in perceptions about the role of the oral historian as interviewer and analyst from the late 1980s; and the digital revolution from the late 1990s onwards. Although there is not space here to attempt a parallel review of geography's evolution over the period, similar intellectual and methodological currents can be traced. It can be seen that there is much within the

\footnotetext{
${ }^{1}$ Thompson suggests the more overt links in Evans' work to that of folklore studies were reduced in the more critical work of subsequent oral historians of this period as such "folklore studies never escaped the stigma of amateurism" (1988, p. 71-72).

${ }^{2}$ There have arguably been much closer links, in the development of oral history, with the disciplines of sociology, anthropology, psychology and linguistics.

${ }^{3}$ Talking Landscapes: on Geography and the Practice of Oral History, one day Symposium, sponsored by the AHRB, University of Exeter, $8^{\text {th }}$ July 2004.
} 
contested history of oral history that can be drawn upon by geographers and, as the papers presented here demonstrate, much that geographers cancontribute to this discussion.

\section{Oral History: retrospect and prospect}

One of the overriding interests within oral history has been to give voice to those that have - using Sheila Rowbotham's (1973) now famous phrase - been 'hidden from history'. While this is characterised by Perks and Thomson (2006) as the first paradigm within the development of oral history this political commitment to opening up undocumented histories is still a central tenet in the sub-discipline of oral history as well as an important motivation for those adopting an oral history methodology within geographical research (McDowell, 2003). These earlier, pioneering, oral historians were criticised on two main fronts. First, (and with a caution that persists for those studies attempting to 'uncover history' today) was a criticism of the perceived 'facile democratisation' (Passerini, 1979) of these accounts which, it was argued, represented a one-dimensional and unproblematic approach satisfied with merely 'collecting people's lives'. Secondly, positivist critiques of the 'reliability' of oral history centred on a questioning of personal bias of interviewers and interviewees and a more fundamental concern with the selective nature of memory which, it was argued, is subject to physical deterioration and nostalgic, often selective, recollection in old age (Hobsbawm, 1988; O'Farrell, 1983). The subsequent responses from oral historians have, as we will discuss below, led a to a fruitful (re)consideration of methodology and practice within oral history. It is worth noting however that for many, this recording of experiences that are often ignored historians is still a justification in itself, particularly in the voluminous local and community-based projects that exist (Bornat, 1989).

The response by oral historians to positivist critiques, has seen the emergence of three areas of debate and development a critical examination of oral history methodology; a reappraisal of the 'subjectivity of memory'; and, in retort to their positivist critics, a broader challenge to 'traditional historical practice' (Samuel, 1994). In a critical reappraisal of methodology, oral historians looked for interdisciplinary guidance turning to psychology and anthropology to help address issues of the bias and fabrication of memory and the impact of retrospection; to documentary history for conventions of checking the internal consistency of sources; and to sociology for adopting methods of representative sampling (Perks \& Thomson, 2006). At the same time, geography was "beginning to realize that masses of numerical data and sharp analytical tools are not in themselves enough" (Smith, 1976 , p.84), with feminist theory at the forefront of raising fundamental questions concerning ontology, epistemology and methodology (Women in Geography Study Group, 1984).

The second thread of this paradigmatic shift countered the criticism of the apparent unreliability of memory with oral historians arguing that this "so-called unreliability [...] was also its strength, and that the subjectivity of memory provided clues not only about the meanings of historical experience but also the relationships between past and present, between memory and personal identity, and between individual and collective identity" (Perks \& Thomson, 2006, p.3). Oral history, therefore, became a central object of study, rather than simply a methodological approach. Memory, narrative and subjectivity became key themes of interest as oral historians, like social scientists, engaged with the "narrative turn' to consider the ways in which individual life experiences are 'storied', and how this 
narrative construction is temporally and spatially variable within different socio-cultural contexts (Frisch, 1990). Perhaps the most significant contribution to this second paradigm came from Raphael Samuel (1994) who turned many of the criticisms levelled at oral history onto 'traditional historical practice', outlining the twin phenomena of 'archive fethishism' and deference towards 'expert voices'. Academic training, Samuel argued, predisposed researchers to give a privileged place to the written word, and to hold the visual and the verbal in comparatively low esteem. "Modern conditions of research seem to dictate an almost complete detachment from the material environment [...]. Blessed (or burdened) with a superabundance of records, we see no need to augment their number but are content to wait on the archivist and librarian, devoting our energies instead to record linkage or to the exploitation of hitherto neglected files" (Samuel 1994, p. 269). Rather than make do with constructing straightforward and 'objective' academic accounts from the official record, therefore, we should strive to use existing material creatively and uncover innovative, ambiguous and challenging routes through which to explore our subject matter

In terms of heeding Samuel's plea to be critical and self-reflexive when dealing with sources, the discipline of geography has been at the forefront of grappling with issues of partiality and subjectivity (Cook et al 2000, Benko and Strohmayer 2004). Indeed, there is a welcome recognition that the presentation and 'doing' of academic study necessarily involves ideology and bias, and that knowledge and understanding are always manufactured. The scepticism of social science objectivity that has been concomitant to this programme of critical self review has led to a flowering of work that utilizes a variety of (mostly qualitative) techniques and methodologies that are characterized, not by their claim to be able to reveal a singular and verifiable 'truth', but to both problematize existing meta-narratives, as well as to sketch a world that is socially constructed and contingent, and where knowledges are situated (Haraway 1991, Cloke et al 2005).

Not entirely distinct from their second phase within oral history research, Perks \& Thomson's (2006) third phase focussed specifically on the theme of the 'objectivity' of the oral historian as researcher and analyst. Interests within this period mirrored those in geography, as strucutralist and materialist approaches were complemented with theories more sensitive to human agency, relationality and contingency (Hubbard et al., 2002), turning particularly to feminist theory in discussing the importance of power, language and meaning within research, and the interview process specifically (Yow, 1997). The fourth paradigm within Perks \& Thomson's (2006) schemata is what they have called the 'digital revolution', through which oral historians have considered the new technologies in which oral history accounts are recorded, preserved, manipulated and disseminated.

\section{Geography and Oral History}

Andrews et al (2006, p.170) advocate the potential of oral histories for specifically geographical enquiry, suggesting that "[they] clearly demonstrate unique insights into the history of places. Indeed, what these narratives provide is recollection about self, about relationships with others and a place, insights rarely provided in such depth by other methods". While studies by oral historians have dealt with key geographical themes, often considering specific places and peoples connections to them, Andrews et al, (2006) point to three key differences in the treatment of place within these studies and its treatment within human geography. First, place has been largely treated by oral historians in a superficial, 
euclidian, manner - a frame for research rather than an active part. Second, and related, these oral histories have engaged little with the theorisations of place from geography, with themes of scale and the construction of place identity and memory largely under studied. Third is a lack of attention to the geographies of the mundane and everyday in terms of space and place - a theme that geographers have recently called attention to (see Holloway \& Hubbard, 2001). The papers presented in this themed issue illustrate some of the ways in which an oral history approach can be utilised within geographical research and how geography can form part of this ongoing critical reassessment of oral history. Two prevalent themes can be seen as central to this endeavour. First, albeit in a more critical manner than previous work in oral history, is a continuation of the core idea of uncovering 'hidden histories', and this feeds into a second theme of a deeper consideration of the themes of space and place which have, hitherto, been overlooked, or at least unproblematised, within oral history research.

While the papers presented here still have a common commitment to uncovering 'hidden voices'there are a variety of experiences portrayed, with the nature of these 'voices', and extent to which they are 'hidden', being different in each of the papers. Indeed, in a position that is almost antithetical to the traditional fare of oral historians, the 'voices' whom Matless et al 'uncover' are those of a privileged academic elite, who arguably already had/have a very strong 'voice'. Rather than providing a space for classically 'marginalized' people, therefore, Matless et al's research works through using an oral history approach to elicit information from key informants that would otherwise not be available by revealing personal and unofficial accounts of British/Soviet academic encounters. The potential of oral history to engage with geography are highlighted in two ways within this paper. First is the consideration of writing historical narrative (Wishart, 1997), where oral history can be added to recent interest in sources such as travel writing (Gruffudd et al., 2000) and biography (Lorimer, 2006) in the construction of historical landscapes. Second, the work demonstrates the potential of oral history to add another dimension to work on the histories of the discipline and formation of geographical knowledges (Barnes, 2006; Lorimer, 2003) helping us, as Matless et al suggest, "reveal the messy and/or deeper truth".

Place memory and place identity are important themes within the few recent examples of geographical research that have used oral history, exemplified by studies of the experiences of previously 'unheard' groups such as the Ukranian diaspora of Bradford, UK (Smith and Jackson 1999), Latvian women migrant workers in post-war British cities (McDowell 2003) or British Asian women in London (Tolia-Kelly 2004). The papers of Ní Laoire and Riley and Harvey carry forward and elaborate on these themes. Ní Laoire builds on the growing geographical literature considering the temporal, social and place embeddedness of migration decisions. In contrast to the other papers presented here, it is not the articulation of voices that are rarely heard (Riley and Harvey), nor the uncovering of untold narratives of named individuals (Matless et al) that forms the central methodological consideration, but rather, the provision of an anonymous 'safe space' in which return migrants can express their thoughts and feelings. In this case, the common theme of ambiguity and reflection comes through in dealing with the issue of how such consciously 'hidden' stories can be made available to a wide audience. 
In the paper by Jones and Fowler, an oral history approach is used to provide fresh insights into a theoretical debate about the construction of the nation. Using oral history to get beyond the old question of whether nations are forged by an intelligentsia or a mass population, Jones and Fowler seek to blur the boundaries of such a dichotomy by focusing on the reception and performance of the nation through individual oral narratives. For Riley and Harvey on the other hand, the process of 'uncovering hidden voices' involves the provision of space for oral accounts to disrupt official narratives and inform detailed practice, from people who are perceived as being marginalized from the scientific process of countryside agri-environmental conservation policy formation. The issue of scale is important here, as place-specific, local, personalized and practice-based oral accounts are used to disturb the longitudinally expert-driven metanarratives of countryside conservation. On one level, therefore, oral histories act to provide an alternative strand of knowledge; that of the 'place- and practice-specific insider', that can be utilized to inform conservation practice at a local scale. On another level, however, these oral histories of the rural landscape act to disrupt unproblematic and one-dimensional accounts of the landscape, reminding us of the importance of the personalized and lived experiences of individuals. To elucidate these specific geographies the paper considers the methodological approaches of 'in-the-field', intergenerational, and artefact-centred interviews.

Looking forward, the papers here offer ideas about the ways in which oral history can be moved from "a rarity or 'add-on"" (Andrews et al., 2006, p.157) to a more central place within geographical research. Andrews et al (2006) conclude their paper with a number of questions about the potential of oral history within geography - some of which this collection addresses, and some which it leaves to be explored. The current interest within the sub-discipline of oral history with the 'digital revolution' perhaps offers one route for disciplinary linkages. Geographers too have investigated the new ways of recording and (re)presenting oral histories (Butler \& Miller, 2005) and the problems associated with this (Ní Laoire, this volume). Perhaps more significantly geographers can lend their experience to discussing the geographies created by these new technologies and the associated places left (Ní Laoire, this volume); places lost (Bayliss, 2003); and how these places are remembered (Bailey \& Bryson, 2006, Riley and Harvey, this volume).

\section{Bibliography:}

Andrews, G. J., Kearns, R. A., Kontos, P. \& Wilson, V. (2006) 'Their finest hour': older people, oral histories, and the historical geography of social life, Social \& Cultural Geography 7: 153-177.

Bailey, A. R. \& Bryson, J. R. (2006) Stories of suburbia (Bournville, UK): from planning to people tales, Social and Cultural Geography 7: 179-198.

Barnes, T. J. (2006) Geographical intelligence: American geographers and research and analysis in the Office of Strategic Services, Journal of Historical Geography 32: 149-168.

Bayliss, D. (2003) Building better communities: social life on London's cottage council estates, 1919-1939, Journal of Historical Geography 29: 376-395. 
Benko, G. and Strohmayer, U. (eds), (2004) Human Geography: A History for the $21^{\text {st }}$ Century. London: Arnold.

Bornat, J. (1989) Oral history as a social movement: reminiscence and older people, Oral History 17.

Butler, T. \& Miller, G. (2005) Linked: a landmark in sound, a public walk of art, Cultural Geographies 12: 77-88.

Cloke, P., Crang, P. and Goodwin, M. (eds), (2005) Introducing Human Geographies. London: Hodder Arnold.

Cook, I., Crouch, D., Naylor, S. and Ryan, J. (eds), (2000) Cultural Turns/Geographical Turns. Harlow: Prentice Hall.

Evans, G. E. (1965) Ask the Fellows who Cut the Hay. London: Faber and Faber.

Frisch, M. (1990) The Memory of History, in Frisch, M. (ed.), A Shared Authority: Essays on the Craft and Meaning of Oral and Public History. Albany: State University of New York Press, pp. 8-23.

Gruffudd, P., Herbert, D. T. \& Piccini, A. (2000) In search of Wales: travel writing and narratives of difference, 1918-50, Journal of Historical Geography 26: 589-604.

Haraway, D.J. (1991) Simians, Cyborgs and Women: the Re-invention of Nature. London: Routledge.

Hobsbawm, E. (1988) On history from below, in Hobsbawm, E. (ed.) On History. London: Weidenfeld and Nicolson, pp. 266-286.

Holloway, L. \& Hubbard, P. (2001) People and Place: the Extraordinary Geographies of Everyday Life. Harlow: Prentice Hall.

Hubbard, P., Kitchin, R., Bartley, B. and Fuller, D. (2002) Thinking Geographically: Space, Theory and Contemporary Human Geography. London: Continuum.

Lorimer, H. (2003) Telling small stories: spaces of knowledge and the practice of geography, Transactions of the Institute of British Geographers 28: 197-217.

Lorimer, H. (2006) Herding memories of humans and animals, Environment and Planning D-Society and Space 24: 497-518.

McDowell, L. (2003) The particularities of place: geographies of gendered moral responsibilities among Latvian migrant workers in 1950s Britain, Transactions of the Institute of British Geographers 28: 19-34.

O'Farrell, P. (1983) Oral history: facts and fiction, Oral History Association of Australia Journal 5: 3-9.

Passerini, L. (1979) Work ideology and consensus under Italian fascism, History Workshop 8: 82-108.

Perks, R. and Thompson, A. (1998) The Oral History Reader. London: Routledge.

Perks, R. and Thomson, A. (2006) Critical Developments, in Perks, R. and Thomson, A. (eds) The Oral History Reader: Second Edition. London: Routeledge, pp. 1-14.

Rowbotham, S. (1973) Hidden from History. 300 Years of Women's Oppression and the Fight Against it. London: Pluto Press.

Samuel, R. (1994) Theatres of Memory. London: Verso.

Smith, D. (1976) To what extent is the geographer's world the 'real world' - invited comment, Area 8: 83-84.

Smith, G. and Jackson, P. (1999) Narrating the nation: the 'imagined community' of Ukrainians in Bradford, Journal of Historical Geography 25: 367-387.

Thompson, P. (1988) The Voice of the Past: Oral History. Oxford: Oxford University Press. 
Tolia-Kelly, D. (2004) Locating processes of identification: studying the precipitates of rememory through artefacts in the British Asian home, Transactions of the Institute of British Geographers 29: 314-329.

Wishart, D. (1997) The selectivity of historical representation, Journal of Historical Geography 23: 111-118.

Women in Geography Study Group. (1984) Geography and Gender: an Introduction to Feminist Geography. London: Hutchinson.

Yow, V. (1997) "Do I like them too much?" Effects of the oral history interview on the interviewer and vice-versa, Oral History Review 24: 55-79. 